\title{
KEWENANGAN PENGADILAN NIAGA INDONESIA DALAM EKSEKUSI ASET DEBITOR PAILIT YANG BERADA DI LUAR NEGERI*,
}

\author{
Oleh : \\ I Dewa Agung Deandra Juniarta**, \\ Ida Ayu Sukihana***, \\ Program Kekhususan Hukum Perdata \\ Fakultas Hukum Universitas Udayana
}

\begin{abstract}
ABSTRAK
Berjalannya perkembangan dunia usaha, debitor memiliki aset baik di dalam negeri maupun di luar wilayah Republik Indonesia. Debitor yang memiliki aset di luar wilayah Republik Indonesia menimbulkan suatu aspek internasional. Menjadi suatu permasalahan jika debitor dinyatakan pailit oleh Pengadilan Niaga Indonesia dan memiliki sejumlah aset di luar negeri karena melibatkan kedaulatan negara. Permasalahan yang diangkat yakni bagaiamanakah pengaturan hukum kepailitan lintas batas negara di Indonesia dan apakah pengadilan niaga Indonesia dapat mengeksekusi aset debitor pailit yang berada di luar negeri. Tujuan penulisan ini untuk mengetahui kewenangan pengadilan niaga Indonesia dalam eksekusi aset debitor pailit yang berada di luar negeri. Metode yang dipakai dalam penulisan karya ilimiah ini adalah metode penelitian normatif dengan meneliti bahan pustaka. Kesimpulannya yaitu pengaturan hukum kepailitan di Indonesia belum mengatur secara jelas mengenai kepailitan lintas batas negara dan pengadilan niaga Indonesia tidak dapat mengeksekusi aset debitor yang berada di luar negeri kecuali dengan diadakannya perjanjian bilateral.
\end{abstract}

Kata Kunci : Kepailitan Lintas Batas Negara, Pengadilan Niaga Indonesia, Aset Debitor

\section{ABSTRACT}

With the development of the business world, debtors have assets both domestically and outside the territory of the Republic of

* Di luar ringkasan skripsi.

** I Dewa Agung Deandra Juniarta adalah mahasiswa Fakultas Hukum Universitas Udayana, andradeandra25@gmail.com.

*** Ida Ayu Sukihana adalah dosen Fakultas Hukum Universitas Udayana, ayu_sukihana@yahoo.com. 
Indonesia. Debtors who have assets outside the territory of the Republic of Indonesia will create an international aspect. It become a problem if the debtor is declared bankrupt by the Indonesian Commercial Court and owns a number of assets abroad because it involves State sovereignty. The problems raised are how are the cross-border insolvency law regulations in Indonesia and whether the Indonesian commercial court can execute the assets of bankrupt debtors abroad. The purpose of this paper is to find out the authority of the Indonesian commercial court in the execution of assets of bankrupt debtors abroad. The method used in writing this scientific work is a normative research method by examining library research. The conclusion is that bankruptcy law regulations in Indonesia have not clearly regulated cross-border bankruptcy and the Indonesian commercial court cannot execute debtor assets abroad except with the holding of bilateral agreements.

\section{Keywords : Cross-Border Insolvency, Indonesian Commercial Court, Debtor Assets}

\section{PENDAHULUAN}

\subsection{Latar Belakang}

Adanya krisis moneter yang terjadi di Indonesia pada pertengahan tahun 1997 telah memberi pengaruh buruk bagi perekonomian nasional, salah satunya kemampuan debitor untuk membayar utang-utangnya kepada kreditor. Kepailitan seakan menjadi trend dalam pemberesan utang piutang pada saat itu. Pada saat debitor tidak bisa lagi membayar utang-utangnya kepada kreditor, maka debitor maupun kreditornya dapat mengajukan pailit. ${ }^{1}$

Kepailitan diatur di dalam Undang-Undang Nomor 37 Tahun 2004 tentang Kepailitan dan Penundaan Kewajiban Pembayaran Utang (selanjutnya disebut Undang-Undang Kepailitan). Berdasarkan Pasal 1 ayat (1) Undang-Undang Kepailitan menjelaskan "Kepailitan adalah sita umum atas semua harta kekayaan debitor pailit yang pengurusan dan pemberesannya

1 Susanti Adi Nugroho, 2018, Hukum Kepailitan di Indonesia, Prenadamedia Group, Jakarta, h. 32. 
dilakukan oleh kurator di bawah pengawasan hakim pengawas". Dijatuhinya putusan pailit terhadap debitor akan menimbulkan suatu akibat hukum, yakni hilangnya kewenangan debitor untuk mengelola harta kekayaannya. ${ }^{2}$ Hal yang dituangkan dalam undang-undang kepailitan ini tentunya dapat menjadi sebuah warning sign bagi para pelaku usaha yang berkedudukan sebagai debitor. $^{3}$

Berjalannya perkembangan dunia usaha, debitor memiliki aset yang berada di dalam negeri maupun di luar wilayah Republik Indonesia. Debitor yang memiliki aset di luar wilayah Republik Indonesia akan menimbulkan suatu aspek internasional, akan menjadi suatu permasalahan jika debitor dinyatakan pailit oleh Pengadilan Niaga Indonesia dan memiliki sejumlah aset di luar negeri karena melibatkan kedaulatan negara. ${ }^{4}$

Dijatuhinya putusan pailit oleh Pengadilan Niaga Indonesia terhadap debitor yang memiliki aset di luar negeri menimbulkan masalah kepailitan lintas batas negara. Permasalahan tersebut terletak pada kewenangan Pengadilan Niaga Indonesia dalam mengeksekusi aset debitor yang berada di luar negeri. Penolakan eksekusi terhadap putusan pengadilan asing terkait erat dengan konsep kedaulatan negara. ${ }^{5}$

Undang-Undang Kepailitan belum memiliki aturan hukum yang jelas untuk menangani kasus kepailitan lintas batas negara. Tidak adanya ketentuan khusus mengenai cara menyelesaikan putusan pailit yang dinyatakan Pengadilan Niaga Indonesia

${ }^{2}$ Sutan Remi Sjahdeini, 2016, Sejarah, Asas, dan Teori Hukum Kepailitan Edisi Kedua, Prenadamedia Group, Jakarta, h. 97-98.

3 Gedalya Iryawan Kale, A.A.G.A. Dharmakusuma, 2018, "Syarat Kepailitan Sebagai Bentuk Perlindungan Hukum Debitor Dalam UndangUndang Nomor 37 Tahun 2004", Kertha Semaya, Vol. 06, No. 03, Mei 2018, h. 3, URL: https://ojs.unud.ac.id/index.php/kerthasemaya/article/view/40730 diakses tanggal 2 Juli 2019.

4 Jono, 2017, Hukum Kepailitan, cet. V, Sinar Grafika, Jakarta, h. 188.

5 Susanti Adi Nugorho, op.cit, h. 419. 
terhadap aset debitor pailit yang ada di luar negeri menimbulkan suatu permasalahan dalam hal eksekusinya.

Pentingnya hukum kepailitan lintas batas negara seharusnya dipikirkan untuk diatur di dalam Undang-Undang Kepailitan di Indonesia agar tidak menimbulkan suatu kebingungan bagi penegak hukum maupun masyarakat terhadap permasalahan di dalam kepailitan lintas batas negara.

\subsection{Rumusan Masalah}

Berdasarkan latar belakang di atas, maka dapat dirumuskan beberapa permasalahan yakni:

1. Bagaimanakah pengaturan hukum kepailitan lintas batas negara di Indonesia?

2. Apakah Pengadilan Niaga Indonesia dapat mengeksekusi aset debitor pailit yang berada di luar negeri?

\subsection{Tujuan}

Tujuan penulisan karya ilmiah ini adalah untuk mengetahui hukum kepailitan lintas batas negara, khususnya kewenangan Pengadilan Niaga Indonesia dalam hal eksekusi aset debitor pailit yang berada di luar negeri.

\section{ISI MAKALAH}

\subsection{Metode Penelitian}

Jenis penelitian yang digunakan dalam penelitian ini yaitu dengan menggunakan penelitian hukum normatif. Metode penelitian hukum normatif atau metode penelitian hukum kepustakaan adalah metode atau cara yang dipergunakan di dalam penelitian hukum yang dilakukan dengan cara meneliti bahan pustaka yang ada. Teknik kepustakaan dilakukan dengan 
sistem kartu dimana dicatat dan dipahami isi dari masing-masing informasi yang diperoleh dari bahan hukum tersebut. ${ }^{6}$

\subsection{HASIL DAN PEMBAHASAN}

\subsubsection{Pengaturan Hukum Kepailitan Lintas Batas Negara di Indonesia}

Dapat dilihat dalam sejarah hukum kepailitan di Indonesia, pengaturan kepailitan di Indonesia telah mengalami banyak perkembangan dan pembaharuan. Mulai dari faillisementsverordening yang menjadi dasar hukum kepailitan di Indonesia pada tahun 1893, lalu berkembang menjadi Perpu No. 1 Tahun 1998 yang kemudian ditetapkan oleh Dewan Perwakilan Rakyat menjadi Undang-Undang No. 4 Tahun 1998, dan setelah banyak evaluasi dan penyempurnaan menjadi Undang-Undang No. 37 Tahun 2004 tentang Kepailitan dan Penundaan Kewajiban Pembayaran Utang.

Menurut Munir Fuady, pailit atau bangkrut adalah suatu sitaan umum atas seluruh harta debitor agar dicapainya perdamaian antara debitor dan para kreditor atau agar harta tersebut dapat dibagi secara adil di antara para kreditor, ${ }^{7}$ sedangkan kepailitan lintas batas negara atau cross-border insolvency adalah suatu kasus kepailitan yang melintasi batas teritorial negara sehingga melibatkan unsur asing di dalamnya. Kepailitan lintas batas negara disebabkan karena adanya transaksi bisnis internasional yang memungkinkan debitor memiliki kreditor di luar negeri maupun debitor memiliki sejumlah aset di luar negeri. ${ }^{8}$

6 Soerjono Soekanto dan Sri Mamudji, 2009, Penelitian Hukum Normatif Suatu Tinjauan Singkat, PT Raja Grafindo Persada, Jakarta, h. 13.

7 Munir Fuady, 2017, Hukum Pailit Dalam Teori dan Praktek, Cet. VI, Citra Aditya Bakti, Bandung, h.5.

8 Susanti Adi Nugroho, op.cit, h. 418. 
Undang-Undang Kepailitan di Indonesia sendiri belum mengatur secara jelas mengenai kepailitan lintas batas negara atau cross-border insolvency ini. Tidak adanya ketentuan khusus mengenai cara menyelesaikan permasalahan kepailitan lintas batas negara menyebabkan kesulitan jika nantinya terjadi suatu kasus kepailitan lintas batas negara dalam perkara kepailitan di Indonesia. Pengaturan Kepailitan Lintas Batas Negara dalam Undang-Undang Kepailitan juga masih bertentangan dengan asasasas hukum perdata internasional yang akan menimbulkan ketidakpastian hukum dalam penanganannya jika terjadi suatu permasalahan kepailitan lintas batas negara di Indonesia. ${ }^{9}$

Pengaturan yang ada dalam Undang-Undang Kepailitan di Indonesia hanya sebatas ketentuan-ketentuan hukum internasional. Ketentuan-ketentuan hukum internasional tersebut telah diatur di dalam Pasal 212, 213, dan 214 Undang-Undang Kepailitan. Pengaturan dalam Pasal 212, 213, dan 214 UndangUndang Kepailitan menyatakan bahwa kreditor dapat mengambil seluruh atau sebagian piutangnya yang ada di luar wilayah Negara Republik Indonesia.

Kepailitan lintas batas negara atau cross-border insolvency juga menyangkut hukum kepailitan negara lain, maka dari itu hukum kepailitan lintas batas negara seharusnya mengatur beberapa aspek, antara lain jurisdiksi hukum kepailitan mana yang akan digunakan untuk menangani proses kepailitan terhadap debitor pailit dan pengadilan mana yang berwenang mengeksekusi putusan pailit tersebut. Sejalan dengan permasalahan tersebut, kepailitan lintas batas negara atau cross-

9 Putu Ayu Ossi Widiari, A.A. Sri Indrawati, 2018, "Pengaturan Terhadap Kepailitan Transnasional di Indonesia", Kertha Semaya, Vol. 06, No. 03, Mei 2018,h.9,URL:https:/ / ojs.unud.ac.id/index.php/kerthasemaya/article/view/40 726 diakses tanggal 25 Mei 2019. 
border insolvency mengenal dengan adanya dua prinsip, yaitu prinsip universal dan prinsip teritorial. ${ }^{10}$

Prinsip universal memiliki makna bahwa suatu putusan kepailitan yang diputuskan oleh pengadilan dari suatu negara memiliki akibat hukum dimana pun kekayaan milik debitor pailit berada, termasuk kekayaan yang terletak di luar wilayah dari negara tempat diputuskannya putusan pailit tersebut. ${ }^{11}$ Melalui prinsip universal, seorang debitor yang dinyatakan pailit akan memberikan akibat hukum terhadap harta kekayaannya dimana pun harta tersebut berada. ${ }^{12}$ Prinsip universal juga terkandung di dalam Pasal 212, 213, dan 214 Undang-Undang Kepailitan.

Adapun prinsip teritorial adalah prinsip yang membatas berlakunya putusan pailit pada suatu negara. Menurut prinsip teritorial, kepailitan hanya mengenai bagian harta benda yang terletak di dalam wilayah negara tempat putusan tersebut ditetapkan. Prinsip ini juga dapat diartikan bahwa kepailitan hanya mengenai bagian harta benda yang terleak di dalam wilayah negara tempat putusan diucapkan. ${ }^{13}$

Prinsip teritorial menyebabkan akibat hukum terhadap putusan pernyataan pailit Pengadilan Niaga Indonesia tidak bisa mengeksekusi harta debitor pailit yang berada di luar wilayah Negara Republik Indonesia. Hal tersebut terjadi dikarenakan adanya konsep kedaulatan negara yang membatasi wewenang Pengadilan Niaga Indonesia dalam eksekusi aset debitor yang berada di luar wilayah Negara Republik Indonesia.

Berdasarkan prinsip teritorial putusan pernyataan pailit dari pengadilan asing yang tidak dapat dieksekusi di Pengadilan Niaga

\footnotetext{
10 Sutan Remi Sjahdeini, op.cit, h. 508.

11 Susanti Adi Nugroho, op.cit, h. 421.

12 Jono, op.cit, h. 189.

13 Jono, loc.cit.
} 
Indonesia, berlaku juga bagi putusan pernyataan pailit Pengadilan Niaga Indonesia yang tidak dapat mengeksekusi harta pailit dari debitor yang berada di luar negeri. Hal tersebut terjadi karena dianggap sebagai suatu pelanggaran terhadap asas kedaulatan negara. ${ }^{14}$

\subsubsection{Wewenang Pengadilan Niaga dalam Eksekusi Aset Debitor Pailit yang Berada di Luar Negeri}

Pengadilan niaga berwenang menjatuhkan putusan yang daerah hukumnya meliputi daerah tempat kedudukan debitor, apabila debitor telah meninggalkan Indonesia maka pengadilan yang berwenang menjatuhkan putusan adalah pengadilan yang daerah hukumnya meliputi tempat kedudukan debitor terakhir. ${ }^{\mathbf{1 5}}$

Kepailitan lintas batas negara atau cross-border insolvency pada dasarnya melibatkan kepentingan dua negara yang berbeda, yaitu terdapat suatu keadaan dimana kreditor dan debitor merupakan dua subyek hukum yang bertempat tinggal di satu negara yang sama, tetapi debitor memiliki sejumlah aset di beberapa negara sehingga keadaan tersebut melibatkan kedaulatan negara yang berbeda dalam proses penyelesaian kepailitannya. Kreditor yang menyatakan permohonan pernyataan pailit kepada debitor, maka putusan pernyataan pailit tersebut tidak dapat langsung dieksekusi karena telah melintasi kedaulatan negara dari tempat aset debitor tersebut berada. ${ }^{16}$

14 Susanti Adi Nugorho, op.cit, h. 425.

15 Ni Putu Agustini Ari Dewi, A.A. Ngr Yusadarmadi, 2013, "Peran Pengadilan Niaga Sebagai Lembaga Penyelesaian Perkara Kepailitan", Kertha Semaya, Vol. 01, No. 05, Juli 2013, h.4, URL: https://ojs.unud.ac.id/index.php/kerthasemaya/article/view/6208 diakses tanggal 2 Juli 2019.

16 Loura Hardjaloka, 2015, "Kepailitan Lintas Batas Perspektif Hukum Internasional dan Perbandingannya Dengan Instrumen Nasional di Beberapa Negara", Yuridika Fakultas Hukum Universitas Airlangga Vol.30,No.3, September 2015,h.484,URL:https://222.ejournal.unair.ac.id/YDK/search/authors/view?fir stName $=$ Hardjaloka\&affiliation $=$ Fakultas $\% 20$ Universitas $\% 20$ Indonesia\&country $=$, diakses tanggal 25 Mei 2019 . 
Berdasarkan sistem hukum perdata internasional di Indonesia, putusan pernyataan pailit terhadap debitor yang memiliki sejumlah aset di luar wilayah Republik Indonesia menganut prinsip teritorial, sehingga putusan pernyataan pailit yang dinyatakan di Pengadilan Niaga Indonesia tidak memiliki akibat hukum terhadap aset debitor yang berada di luar wilayah Republik Indonesia, putusan pernyataan pailit tersebut hanya memiliki akibat hukum terhadap aset debitor yang berada di dalam wilayah Republik Indonesia. ${ }^{17}$

Negara yang menganut prinsip territorial dalam menyelesaikan masalah kepailitan lintas batas negara tidak memperkenankan pengadilannya untuk mengeksekusi putusan pengadilan asing, ataupun sebaliknya. Berbeda dengan negara yang menganut prinsip universal dalam menyelesaikan masalah kepailitan lintas batas negaranya, dikarenakan negara yang menganut prinsip universal menganggap suatu putusan pailit berlaku di seluruh dunia sehingga putusan pailit yang diputuskan di suatu negara memiliki akibat hukum di manapun debitor yang dinyatakan pailit tersebut berada. ${ }^{18}$

Pada dasarnya suatu negara yang menganut prinsip teritorial memperbolehkan Pengadilan Niaganya untuk mengeksekusi putusan pailit terhadap aset debitor yang berada di negara lain apabila terdapat sebuah perjanjian internasional antar kedua negara tersebut. Tiap negara yang menganut prinsip teritorial dalam pemberesan kepailitan lintas batasnya harus melakukan sebuah perjanjian bilateral. Dengan diadakannya perjanjian bilateral dalam suatu masalah kepailitan lintas batas negara atau cross-border insolvency, maka memungkinkan adanya

17 Susanti Adi Nugorho, op.cit, h. 422.

18 M. Hadi Shubhan, 2009, Hukum Kepailitan Prinsip, Norma, dan Praktik di Peradilan, cet. II, Prenada Media Group, Jakarta, h. 89. 
pengakuan putusan pernyataan pailit yang diputuskan di antara kedua negara tersebut dalam proses pemberesan harta pailit. ${ }^{19}$

Selain dengan melakukan perjanjian bilateral antar negara, dalam menyelesaikan kasus kepailitan lintas batas negara atau cross-border insolvency, United Nations Commission On International Trade Law (UNCITRAL) memberikan solusi yang memungkinkan sebuah negara mengakui dan melaksanakan putusan pernyataan pailit yang dinyatakan oleh pengadilan asing. Solusi tersebut berupa UNCITRAL Model Law on Cross-Border Insolvency with Guide to Enactment sehingga memungkinkan putusan pernyataan pailit yang dinyatakan oleh pengadilan asing dapat dieksekusi oleh pengadilan di suatu negara, khususnya jika hal tersebut terjadi di Pengadilan Niaga Indonesia. ${ }^{20}$ Peran dan kehadiran UNCITRAL Model Law on Cross-Border Insolvency with Guide to Enactment sangat relevan dalam kasus kepailitan apabila menyertakan pihak asing serta memiliki aset di beberapa negara. ${ }^{\mathbf{2 1}}$

Model law tersebut tidak membatasi yurisdiksi atau kedaulatan suatu negara terhadap suatu kepailitan lintas batas negara, melainkan memberikan keseragaman aturan dalam penerimaan putusan pernyataan pailit pengadilan asing pada suatu negara. Apabila pengaturan hukum kepailitan di Indonesia mengadopsi model law tersebut, berarti Pengadilan Niaga Indonesia memungkinkan untuk mengeksekusi putusan pernyataan pailit pengadilan asing ataupun Pengadilan Niaga Indonesia dapat mengeksekusi harta debitor pailit yang berada di

19 Ibid, h. 96.

20 Sutan Remy Sjahdeini, op.cit, h. 516-518.

21 Tasuji Wirismalawati, Anak Agung Sri Utari, 2017, "Penerapan UNCITRAL Terhadap Penyelesaian Perkara Kepailitan Lintas Batas Negara Studi Kasus Kepailitan Fairfield Sentry Limited", Kertha Negara, Vol. 05, No. 05, Desember 2017 , h.3, URL: https://ojs.unud.ac.id/index.php/kerthasemaya/article/view/6208 diakses tanggal 2 Juli 2019. 
luar negeri, dan dapat memberikan manfaat bagi para pelaku usaha yang melakukan transaksi bisnis internasional untuk keluar dari suatu permasalahan.

\section{PENUTUP}

\subsection{Kesimpulan}

1. Pengaturan hukum kepailitan lintas batas negara atau crossborder insolvency di Indonesia belum mengatur secara jelas mengenai pemberesan harta debitor pailit yang berada di luar negeri. Pengaturan yang ada dalam Undang-Undang Kepailitan di Indonesia hanya sebatas ketentuan-ketentuan hukum internasional. Ketentuan-ketentuan hukum internasional tersebut telah diatur di dalam Pasal 212, 213, dan 214 Undang-Undang Kepailitan.

2. Pengadilan Niaga Indonesia tidak bisa mengeksekusi aset debitor pailit yang berada di luar wilayah Republik Indonesia karena adanya konsep kedaulatan negara, kecuali dengan diadakannya perjanjian bilateral yang memungkinkan putusan pernyataan pailit Pengadilan Niaga Indonesia dilaksanakan di luar wilayah Republik Indonesia.

\subsection{Saran}

1. Pemerintah Indonesia bersama dengan Dewan Perwakilan Rakyat hendaknya melakukan revisi terhadap UndangUndang No. 37 Tahun 2004 tentang Kepailitan dan Penundaan Kewajiban Pembayaran Utang, khususnya dalam kepailitan lintas batas negara atau cross-border insolvency mengenai pemberesan harta debitor pailit yang berada di luar wilayah Republik Indonesia.

2. Pengaturan hukum kepailitan di Indonesia (Undang-Undang No. 37 Tahun 2004 tentang Kepailitan dan Penundaan Kewajiban Pembayaran Utang) seharusnya meratifikasi 
UNCITRAL Model Law on Cross-Border Insolvency with Guide to Enactment untuk menyelesaikan kasus kepailitan lintas batas negara atau cross-border insolvency.

\section{DAFTAR PUSTAKA}

\section{BUKU:}

Fuady, Munir, 2017, Hukum Pailit Dalam Teori dan Praktek, Cetakan VI, Citra Aditya Bakti, Bandung.

Jono, 2017, Hukum Kepailtan, Cet. V, Sinar Grafika, Jakarta.

Shubhan, M.Hadi, 2008, Hukum Kepailitan: Prinsip, norma, dan Praktik di Peradilan, Kencana, Jakarta.

Sjahdeini, Sutan Remi, 2016, Sejarah, Asas dan Teori Hukum Kepailitan, Edisi 2, Prenada Media, Jakarta.

Soekanto, Soerjono dan Mamudji, Sri, 2009, Penelitian Hukum Normatif Suatu Tinjauan Singkat, PT Raja Grafindo Persada, Jakarta.

Nugroho, Susanti Adi, 2018, Hukum Kepailitan di Indonesia, Prenadamedia Group, Jakarta.

\section{JURNAL:}

Dewi, Ni Putu Agustini Ari, A.A. Ngr Yusadarmadi, 2013, "Peran Pengadilan Niaga Sebagai Lembaga Penyelesaian Perkara Kepailitan", Kertha Semaya, Vol. 01, No. 05, Juli 2013, h.4, URL:https://ojs.unud.ac.id/index.php/kerthasemaya/article/v iew $/ 6208$

Hardjaloka, Loura, 2015, "Kepailitan Lintas Batas Perspektif Hukum Internasional dan Perbandingannya Dengan Instrumen Nasional di Beberapa Negara", Yuridika Fakultas Hukum Universitas Airlangga Vol.30,No.3, September 2015, h. $\quad 484, \quad$ URL: $\quad$ https://222.ejournal.unair.ac.id/YDK/search/authors/view?firstName $=\mathrm{H}$ ardjaloka\&affiliation=Fakultas\%20Universitas\%20Indonesia \&country $=$, 
Kale, Gedalya Iryawan, A.A.G.A. Dharmakusuma, 2018, "Syarat Kepailitan Sebagai Bentuk Perlindungan Hukum Debitor Dalam Undang-Undang Nomor 37 Tahun 2004", Kertha Semaya, Vol. 06, No. 03, Mei 2018, h. 3, URL: https://ojs.unud.ac.id/index.php/kerthasemaya/article/vie $\underline{\mathrm{w} / 40730}$

Widiari, Putu Ayu Ossi, A.A. Sri Indrawati, 2018, "Pengaturan Terhadap Kepailitan Transnasional di Indonesia", Kertha Semaya, Vol. 06, No. 03, Mei 2018, h. 9, URL: https://ojs.unud.ac.id/index.php/kerthasemaya/article/vie $\underline{\mathrm{w} / 40726}$

Wirismalawati, Tasuji, Anak Agung Sri Utari, 2017, "Penerapan UNCITRAL Terhadap Penyelesaian Perkara Kepailitan Lintas Batas Negara Studi Kasus Kepailitan Fairfield Sentry Limited", Kertha Negara, Vol. 05, No. 05, Desember 2017, h.3,URL:https://ojs.unud.ac.id/index.php/kerthasemaya/ar ticle/view/6208

PERATURAN PERUNDANG-UNDANGAN:

Indonesia, 2004, Undang-undang Nomor 37 Tahun 2004 tentang Kepailitan dan Penundaan Kewajiban Pembayaran Utang, Lembar Negara Republik Indonesia Tahun 2004 Nomor 131, Tambahan Lembar Negara Republik Indonesia Nomor 4484, Sekretariat Negara, Jakarta.

Kitab Undang-Undang Hukum Perdata (Burgelijk Wetboek), Subekti dan R. Tjitrosudibio, 2008, Pradnya Paramita, Jakarta. 